\title{
Urbanisation of former city fortifications in The Netherlands between 1805 and 2013
}

\author{
G. A. Verschuure-Stuip ${ }^{1} \&$ B. Labuhn ${ }^{2}$ \\ ${ }^{1}$ Delft University of Technology (DUT), The Netherlands \\ ${ }^{2}$ Independent Researcher, Architect, The Netherlands
}

\begin{abstract}
Nowadays, the revitalisation of former fortification zones surrounding Dutch historic cores enjoys a broad societal interest. They define the historic city cores, the urban identity, enhance the quality of life, and play a role in the ecology, water management and recreation of the city. The revitalisation strategies vary from reconstruction and preservation of the entire fortification system, to revitalisation approaches as well as more narrative approaches. This article provides an general overview of the history of fortifications in the Netherlands, in which there are three major phases: 1) the construction of the fortifications from castles to defence lines and frontier cities; 2) the dismantling of the walls and urbanisation, which started in 1805 and ended in $1951 ; 3$ ) the current spatial character of the fortifications and their transformation, which reflect different heritage approaches in the Netherlands: heritage as a sector, a factor and a vector. Finally, this article aims to define mechanisms of transformation and revitalisation to use the acquired insights for future city planners and landscape architects to define historic inner cities and strengthening urban identity.

Keywords: city fortifications, urban parks, defortification, urbanisation, fragmentation, conservation, reconstruction, revitalisation strategy, spatial transformation, Netherlands.
\end{abstract}

\section{Introduction}

\subsection{Societal challenges concerning the former fortification zones}

When studying Dutch city maps, one can discover many historic city cores that are still enclosed by circular, often curved shaped canals, named 'singel' (Dutch) 
or canals, separating the inner core from the outer neighbouring areas. These water structures often were the former moats, parts of the old fortification system of the city that has been dismantled gradually since 1805 . In numerous cases these zones developed into public city parks, which were called 'city wanderings'. These 'city wanderings' were a new type of $19^{\text {th }}$ century green urban structure, that was developed next to other types of urban green, such as villa parks, zoos, boulevards, etc. $[1,2]$. Besides city parks other functions like cemeteries, mills, factories, universities, museums, dwellings, train stations and roads were situated in these zones [3]. It was until the $20^{\text {th }}$ century before the general public started to show increasing interest in the past of the fortification cities they were living in. The plans for urbanisation of the earthen wall of Naarden led to public resilience which marked a new period of conscious preservation of the Dutch city fortifications [3]. Nowadays, several Dutch cities are considering reconstruction of (parts of) the missing fortification systems (e.g. 's-Hertogenbosch). Other cities are developing more narrative revitalisation strategies, which aim to reconceptualise the unity of the zone (e.g. Leiden) or to reprogram the fortification zone in order to increase its vitality [4]. The need for these transformations can be found in the constant change of these areas, the potential green quality, unique historic relics as well as the green landscape architectural designs. But the needs can also relate to urban ecology (e.g. presence of rare vegetation), urban water management, recreation and other current spatial issues. Municipalities are faced with questions concerning the revitalisation policy, even when most fortifications are fragmented or even gone. How can we give these remains a new place in future developments? Should we restore to an older phase in time or show its transformation? How to deal with the deteriorated greenery in the parks, which was established just after the demilitarisation? These are examples of many questions concerning the revitalisation of former city fortifications and their gradual dismantlement. In order to define future steps, we must understand the past on a general scale as well on specific scale. Therefore, we need more insight in the reasons and pace of dismantlement and urbanisation to understand the diversity in transformation processes of the fortification zones.

\subsection{Aim and structure of the article}

This article has three parts: the construction of the fortifications, their dismantlement and current development. After an introduction on how cities were strengthened and fortified, this article will explore the complex relationship between the period of dismantlement, the socio-political influences, changing war legislation and the resulting spatial character of these zones. This article also aims to start defining different mechanisms of transformation and revitalisation of these areas to use them for future city planners and landscape architects in their search to define historic inner cities and strengthen the urban identity.

\subsection{Previous research}

Previous research on this topic is limited and focusses mostly on the military history. The $19^{\text {th }}$ and early $20^{\text {th }}$ century transformations are mostly covered by 
studies on individual cities and each study focusses on a different aspect of the transformation, rarely connecting societal processes to the spatial transformations. Nevertheless, a few publications proved to be helpful for this article. The transformation of the fortifications into $19^{\text {th }}$ century parks was addressed in the 1980s and 1990s by the Landscape department of Delft University of Technology, leading to an exhibition and publications $[1,2]$. The dissertation of R. Smook focussed on spatial and morphologic changes of a selected group of inner cities, leaving out specific mechanisms. More focussed on mechanisms underlying the transformation processes were the articles in the book 'Vestingen' written by the Foundation Menno Coehoorn [3]. Another significant overview is the introduction of 'Vestingsteden' [5] and an article 'Vestingwerken in Nederland' [6]. But these publications are focussing on the past and present, and do not elaborate on current and future perspectives. In this article, we integrate existing knowledge into a meta-analysis and update it with descriptions of the current developments.

\section{Construction (1231-1940) and dismantlement (1805-1951) of the city fortifications}

\subsection{Construction of strengthened cities and city fortifications}

From the Middle Ages defence of land changed from the protection of smaller areas by dukes into larger fortification structures with strengthened cities. These dukes lived in fortified houses or castles and the cities were strengthened similarly. The first city fortifications were based on the Italian fortification model, resembling the fortifications of castles, and were made out of brickwork, towers, gates and moats (Italian castle-model) [5]. The landowner could grant a city permission to build their city fortifications (1231-1505). When cannons were introduced in warfare (1494-1516), the Italian castle-model became outdated [7]. At the end of the $16^{\text {th }}$ century, the towers were torn down, the walls were lowered and enforced on the inside with earthen ramparts to withstand the high impact of the cannon shots. Many cities were strengthened during this period. A regularly shaped star-plan was introduced, and was constructed on the basis of mathematical calculations of the field of cannon fire. The bastions, the points of the star, were put forward so that the courtines, the long walls between the bastions, could be defended. Inside the ring, two kinds of city patterns were popular: the radial polygonal form, popular with the fortification builders and the grid form, preferred by merchants and city planners [5]. This improved Italian model was used until the Revolt and the Eighty Years' War (1568-1648). During this conflict, due to economic and pragmatic reasons, the Dutch used earthen ramparts instead of brick walls and surrounded it with wide, wet ditches. This system, later well known as the Old-Dutch fortification model, was used in many European cities because it was not only more economic, but also more effective against cannons. The system was improved many times by Simon Stevin (1548-1620), Adriaen Antoniszn (1541-1620) and Menno van Coehoorn (1641-1704), amongst others. Even though many Dutch cities did not modernise their old fortifications due to the high 
costs, the introduction of these new ideas still had a lasting impact on using the landscape characteristics for defence works [5].

\subsection{From strengthened cities to fortified cities and defence lines}

To defend larger areas, specific cities and their surroundings were connected in lines and these cities became frontier cities. In 1672 a number of cities in the Netherlands formed a defence line of frontier cities and areas in between, starting in the very North East to the very South West: Nieuwerschans, Bourtange, Coevorden, Zwolle, Deventer, Zutphen, Doesburg, Arnhem, Nijmegen, Grave, 's Hertogenbosch, Heusden, Geertruidenberg, Bergen op Zoom, Breda, Hulst, Aardenburg and Sluis [8]. Next to this line, the Dutch Waterline was constructed; a long line of inundation fields from Muiden to Gorinchem, closing the route to the province of Holland with large areas of water. Later, Cornelis Krayenhoff (1758-1840) made plans for an improvement. This New Dutch Waterline was a line of both waterworks and inundation fields as well as fortresses, creating a zone of six to eight kilometres of water and military objects. At places where it was more difficult to inundate, access points were defended with military objects, like fortresses and even fortified cities, such as Naarden which was situated in front of the Waterline [9]. Other defence waterlines were the Grebbelinie, Stelling of Amsterdam, IJssellinie, etc. Strengthened and fortified cities behind the waterlines were demilitarised at the end of the $18^{\text {th }}$ and beginning of the $19^{\text {th }}$ century [8].

\subsection{Four periods of defortifications}

As a result of the construction of defence lines, the majority of the Dutch cities were defortified. This took place in the $19^{\text {th }}$ century until the beginning of the $20^{\text {th }}$ century. For most cities, this defortification was needed, because not only the spatial configuration of these cities had changed and the fortifications restricted cities in their urban growth, but also due to economic, social and political needs. Roughly four periods of dismantlement can be distinguished. Each period was directly initiated by different political laws or decisions or as a result of changes in warfare.

Period 1 (1805-1813): During the French period (1798-1815) ideas for the construction of the New Dutch Waterline were worked out and led to initial defortifications. Because of the Peace of Lunéville (1801), several city fortifications were dismantled and transformed into city parks. During these years the cities Arnhem (1808), Kampen (1809), Zwolle (1810), Alkmaar (1810), Amsterdam (1811), Leeuwarden (after 1820), Haarlem (after 1821) and Utrecht (after 1821) started to dismantle their ramparts [3]. Besides that, other strengthened and fortified cities behind the Waterlines were demilitarised.

Period 2 (1854-1874): This period started with the 'Prohibited area law' or 'Kringenwet' from 1854, when only twenty-five cities were appointed to remain fortified, allowing other cities to be dismantled (such as Coevorden (1858), Veere (1861), Bergen op Zoom, Vlissingen, Venlo, Maastricht (1867), Breda (1868) [3]). 
Period 3 (1874-1900): This period started with the publication of the 'Vestingwet' (1874), with which only eleven cities became part of the national defence system, which again allowed other cities to be dismantled, such as Delfzijl, Groningen, Deventer, Zutphen, Nijmegen, Grave en Den Bosch (1874) [3].

Period 4 (1900-1951): The final period started in the beginning of the $20^{\text {th }}$ century, when defence lines became considered outdated. The eleven cities, which were part of these lines were allowed to break down their fortifications: Terneuzen (1908), Geertruidenberg (1919), Doesburg (1923), Naarden (1926), Willemstad (1926), Gorinchem, Brielle, Hellevoetsluis, Muiden (1926), Weesp (1947/51) and Woudrichem (1951) [3]. Plans for the dismantlement of Naarden, were contested by a group of inhabitants, marking a change in attitude toward preservation of the more cultural historical values of these fortifications. As a result, several of these cities followed this example and kept these last remaining fortifications intact, like Woudrichem, Naarden and Brielle.

\section{Urbanisation of city fortifications (1805-1951)}

\subsection{Different functions in urbanisations}

In the 150 years timespan of dismantlement of both strengthened and fortified cities, a considerable amount of factors and decisions influenced the programmatic re-use and spatial transformation of these fortification areas. Although every city has its unique development, looking at a more abstract level, some re-occurring motives influenced the urbanisation of city fortifications, based on similar urban transformations and fashion, inspired by other cities. Two kinds of motives can be distinguished. Firstly, there are several conditions, requirements or functions which were essential on regional or national scale and not decided by the city itself, such as water control or water management, military purposes and other function owned by the state. Some cities used these areas for cemeteries, which were hard to relocate. Secondly, based on their ambition and needs, cities could make free choices (considerations). A very important factor underpinning those decisions was the economic reality concerning ground prizes and investment costs. Before the demilitarisation the fortified ground belonged to the state, but the cities were responsible to co-maintain the works. When the first cities demilitarised, the state often gave them the ground for free on the condition that these grounds would be redeveloped and that the cities would take care of the revitalisation process. For many municipalities the defortification was an economic and juridical puzzle. The dismantlement of the fortification and preparation for building was costly, as the ground had to be displaced. Because of their function in water management, the earthen ramparts could not be removed and e.g. be used to fill the canal. In rare cases the municipalities did nothing; the municipality of Groenlo rented these lands to farmers for grazing ground. The construction of city parks and villa parks was the second cheapest option, because site preparation for construction was not needed. In other cases, the municipality invested in the dismantlement and in the 
site preparation, making it a social employment project. Afterwards, the grounds could be sold to investors who would redevelop 'their piece' of the former fortification zone [3]. In combination with the functions imposed by the state and the already existing functions, these areas became fragmented.

\subsection{Conditions: water control, military areas, cemeteries and others functions}

Nowadays, many Dutch cities have the characteristic curved waterline around the historic city. Because the Dutch lowland is located in the delta of several large European rivers, the country was kept dry through an ingenious system of dikes, ditches, canals, reservoir basins, pumps and dams. The old moats were part of this system of water control and water purification. Next to this, water was important as part of the main transportation routes, connected to the network of city's transportation canals and ports. This can be seen for instance in Bergen op Zoom, Groningen, Harlingen, Middelburg and Zutphen [3]. Only Arnhem, Bergen op Zoom and Nijmegen, followed the example of many other European cities and covered their fortification moats with the earthen ramparts as a practical solution to get rid of the soil [3]. Military functions were kept or even constructed within the former fortification zone like training fields, stables, barracks or military hospitals (Bergen op Zoom, Breda, Deventer, Groningen, Leeuwarden, Utrecht and Zutphen). Sometimes the state reserved the grounds for state institutions like universities (and their botanical gardens), juridical courts or even prisons (Goes, Haarlem, Leeuwarden, Utrecht, Leiden and Zutphen) [3]. Even before the defortification started, many cities constructed cemeteries on the bastions due to the lack of space on existing cemeteries and churches (Dokkum, Elburg, Groenlo, Haarlem and Zaltbommel) [3].

\subsection{Considerations: parks and culture, transport, industry, housing}

The transformation of the former fortification zones into city parks became popular, and introduced the 'city wandering' as a new type of $19^{\text {th }}$ century green [2]. Walking in the fortification zone was not something new. Ever since their construction people were strolling around them, enjoying the view on the surrounding open landscape. When more cities started to demilitarise in the $19^{\text {th }}$ century the construction of parks was considered to be a jewel for the city and a blessing for the health of its inhabitants [3]. Four city parks became exemplary; Arnhem (1829-1835), Haarlem (1820), Leeuwarden (1825 and later) and Utrecht (1829 and later). Landscape architects like J. D. Zocher, L. P. Roodbaard, L. Springer and S. van Lunteren were responsible for many of these public city parks [10]. Later the parks were extended with playgrounds and children's farms, small music halls and other cultural activities [3]. Other city functions were defined for this area, including new railway stations. Since the introduction of the railway in 1839 as a private initiative, tracks and train stations became the new city hubs and the areas between city cores and train stations started to be redeveloped. This led to a new barrier in urbanisation. For pragmatic reasons the train stations were often placed just outside of the fortification zone, with the 
exceptions of Haarlem and Zutphen. Both cities developed stations within the city cores [3]. After 1870 motorways were developed rapidly and many canal parks were replaced by city ring roads, while the waterways were filled in completely (Nijmegen, Bergen op Zoom and Amersfoort) or reduced to smaller canals along the new road (Amsterdam, Arnhem, Breda and Groningen) [3]. In many cases, the rapid economic growth between 1850 and 1870 stimulated the development of the industry in the Dutch cities. New factory complexes were not only placed in the neighbourhood of the railway stations but also at the borders of the cities, often on the (former) fortification walls, where the traffic access was best. Many earlier industrial activities like wind mills and rope yards (streets for production of ropes), were placed in the neighbourhood or on the city fortifications. From mid-19 $9^{\text {th }}$ century also gas factories and other industries were located there [6]. The development of the industries contributed to the increase of work opportunities within the city cores, and as consequence the city population kept on growing, especially after the agricultural crisis from 1874. The increasing density of population led to unhygienic situations in self-built slums. From 1850 on religious and non-religious organisations started to build decent dwellings for these workers. Even municipalities sometimes started to build these labour settlements on the former fortification grounds, such as in Harlingen, Breda, Groenlo, Leeuwarden and Bergen op Zoom. However, accommodating labour settlements was not considered the ideal destination for these fortification zones. Many municipalities preferred to sell the grounds to private investors for the building of villa parks and mansions. These functions were more attractive because of the city prestige and the tax revenues on the long term, as can be seen in Arnhem, Bergen op Zoom, Breda, Coevorden, Deventer, Groenlo, Groningen, Haarlem, Leeuwarden, Nijmegen, Utrecht and Zwolle [3].

\section{Contemporary spatial expression of city fortifications}

The combination of diverse socio-political conditions and considerations have resulted in a different spatial configurations of the fortification zones. These four different spatial types are: 1) preserved fortifications (e.g. Naarden); 2) large scale park structure (e.g. Haarlem); 3) collage of fragments of functions and fortification (e.g. Leiden); and 4) lost fortifications (e.g. Arnhem).

\subsection{Naarden, the preserved city fortifications}

The maintained fortifications of Naarden are an example of the conserved fortification. The strengthened walls were built in 1350 and since then experienced many refurbishments. The current situation resembles the $17^{\text {th }}$ century situation. Both the fortifications, six bastions, double walls and double canals, as well as the 'field of cannon fire' around the fortifications is preserved in the open landscape [11]. When Naarden was allowed to dismantle and the city made transformation plans in 1926, public opinion opposed the ideas on transformation and urbanisation of this area. This was a remarkable step, because after more than a hundred years of dismantling and transformation of the former fortification zones, 
maintaining the fortification as it was and restoring it, became the preferred solution. After a heated debate and the establishment of the Foundation Menno van Coehoorn conservation plans were made. Nowadays, one can take a walk on the top of the ramparts overlooking the surrounding landscape, just like in the past [3].

\subsection{Haarlem, the construction of a large public city park}

The city of Haarlem is an example of the transformation of the former fortification zone into a park zone. It is one of the earliest and most consequent and coherent transformation strategies. Almost two-third of the former fortification zone is transformed into a park in 1836, according to the design of J. D. Zocher (17911870 ) in English landscape style. This style is characterised by panoramic views over the park and landscape, with here and there some views over and into the city. The panoramic view on the surroundings was the main feature of the canal park in Haarlem and made it an exemplary case of the 'city-wandering'. Alternation and composition of dense bushes, open grass fields and semi-transparent plants frame and delineate these panoramic views $[1,3]$. The construction of this canal park more or less preserved the shape of the ramparts and bastions, while only levelling it, is now visible in the form of the water structure. This remarkable coherence in planning has its roots, surprisingly, in an economic decline. In the $18^{\text {th }}$ and $19^{\text {th }}$ centuries, when the city fortifications became abundant, the city coped with an economic crisis and was actually a 'shrinking city'. Therefore, with the construction of the canal-park, which was an investment for the city and a prestigious project, the city hoped to attract more new wealthy inhabitants from the adjacent cities, which led to a success [1]. The city started to grow and in 1880 it even started to expand outside the former city walls, which led to the disappearance of the panoramic view from the park over the landscape [12].

\subsection{Leiden, a case of a collage of fragments along the canal park}

The city of Leiden is an example of a transformation of the former fortifications resulting in a collage of urban fragments along a continuous canal park. The canal park is preserved by the preservation of the moat. The ramparts and bastions are levelled. A continuous road is constructed following the canal park on the outside, while on the inside there is a collage of former city gates, former hospitals, museums, semi-public parks, scattered small public parks, factories, cemeteries, windmills, entrance of the railway station area and traffic breakthroughs. All those bits and pieces of urban functions are not interconnected, so a continuous promenade along the city side of the canal parks is not possible. This fragmentation is a result of a missing plan, lack of urgency and opportunistic development of the canal park [12]. From 1830, the defortification in Leiden started as an employment project. Directly after this, the Hortus Botanicus and the Observatories were designed on the south side of the city. As there was no direct urgency for expansion, the East side and the North side of the city were gradually sold to private investors whenever there was an opportunity for it [12]. 


\subsection{Arnhem: a case of lost fortifications}

The city of Arnhem is an example of the total dissolution of the former city fortifications. This is remarkable, because of its defortifications the 'city wandering' along the former fortification zone in Arnhem was supposedly fabulous and became a shining example for many cities [3]. Already in 1808 Arnhem was ordered to dismantle its fortifications. Due to uncoordinated work, it took until 1829. Because Arnhem is situated on the higher grounds of the Veluwe, which is leading to different water management in this area than the western part of The Netherlands, the moats were filled up. In 1929 the city gates were demolished and directly after that, the zone was initially used for private villa parks and landscape parks. Unfortunately, the following uncoordinated urbanisation started to erase this green zone. Finally, the positioning of the railway and the station completely erased the former city borders. Nowadays, there are completely no marks of the position or shape of the former city fortifications, even not in the street pattern $[3,13]$.

\section{Future urbanisation strategies (1999-2013)}

Since the renewed interest in history and heritage issues and the outcome of the Belvedere memorandum (1999), several Dutch cities started to rediscover their history as fortified cities and took this in their advantage. This led to a growing interest in the revitalisation of the remaining fortifications. One can discern three kinds of future strategies: 1) preservation and reconstruction of the (first) fortification system (e.g. Bourtagne); 2) revitalisation of these green linear areas in which the historic changes are maintained and used (e.g. 's Hertogenbosch); and 3) reconceptualisation of the history of the changing fortification zone, in which the character of the entire zone is part of the unifying concept in which history and current spatial 'problems' are connected in a more narrative way (e.g. Leiden).

Every group can be divided in many different forms in a range of small interventions to large scale transformations. These practices reflect the three basic approaches, which were recently defined in the Dutch national research agenda on heritage and spatial development as 'heritage as a sector, 'heritage as a factor' and 'heritage as a vector' [14].

\subsection{Preservation and reconstruction: Bourtange}

Bourtagne is an (extreme) example of the first full reconstruction of the former fortification zone and of re-use of a fortress as a village. Its original purpose of the star-shaped concentric fortification was to control the main road to Groningen. After the defortification in 1851 a period of long years of uncoordinated urbanisation made the city lose its shape as well as its economic growth. During 1960s the city council decided to reconstruct the old star-shaped city pattern and the star-shaped fortification. The reconstruction started in 1973 and was finished in 1992. Nowadays, Bourtagne looks like it did in 1749 and attracts many tourists 
as a museum city in which time appears to have stood still [15]. This is an example of the approach 'heritage as a sector' that focusses on the preservation of the object (fortification) itself. Because of its focus on the historic objects, Bourtagne becomes a museum of itself [14].

\subsection{Revitalisation: 's Hertogenbosch}

The need for the restoration of the fortification walls of 's Hertogenbosch was used to redefine the image of the city by showing the different phases in transformation of the city fortification. Historic elements, like quay walls were preserved, as well as natural elements (rare wall vegetation). Also in the fortification zone the renewed connection with the river was established to serve public use. The new design is a combination of both restoration of older parts in different phases, as well as new elements, like bridges, iron examples of the old earthen construction and new bastions in a six kilometre green park zone. This historic ensemble was transformed for future use and current spatial issues [16]. This is an example of the approach 'heritage as a factor', that focusses on the ensemble and its historic growth. Different subjects (multi-disciplinary) are combined and there is conservation, restoration, re-use and transformation [14].

\subsection{Reconceptualisation: Leiden}

The plans for the 'longest city park of the Netherlands' in Leiden (as they describe it) is an example of using the narrative of this former fortification zone for a more conceptual approach for the future. The former fortification zone is scattered with public parks, semi-public parks, institutions, cemeteries, traffic hubs and industries. The common aspect is the element of water and a small green zone. The municipality wants to make a six $\mathrm{km}$ long park and respects the existing structures as much as possible [4], while adding new functions. In contrast to the case of Bourtange, Leiden sees the successive re-uses of and physical additions to the fortification walls as a valuable stratification of time. And in contrast with 's Hertogenbosch, the concept of a diverse 'green' line was used as a direction for new use. The redesigned plan is preserving and enforcing the existing diversity, but is also connecting areas by new bridges which lead to small scale demolitions. The different zones preserve their character, but the natural atmosphere is enhanced in every area in its own way. The project is not a master plan, but has a bottom up approach which means that it will be co-shaped by the demands of citizens and entrepreneurs [17]. In this plan the former fortification zone functions thus merely as a 'continuity' concept, which unifies a diversity of bottom-up projects along the 'fortification line' into a recreational zone for the entire city. This last example is showing the third approach 'heritage as a vector'. The always changing history is used for defining a new concept in which the history of the place becomes the guiding theme in the conceptual sense. Here heritage is used as a direction, a vector, of re-use and new transformation connecting it to spatial problems, like water management, shrink and expansion of historic inner cities and quality of inner city-life [14]. 


\section{Concluding remarks}

In the course of history the boundaries of the cities are under constant change. First these border areas were defined by strengthening and later on by fortifications and were dismantled and transformed many times, creating a border and strengthening the urban identity. The dismantlement of these zones started in 1805 and was accomplished in roughly four different periods. This led to diverse spatial characters of fortification zones. Comparing city maps of dismantled cities in the same period show that different approaches were applied. There is no clear unambiguous relationship between the period of the defortifications, the sociopolitical motives and the contemporary spatial configuration. For example, the cities which were first allowed to dismantle their city fortifications are not all elongated parks, like Leeuwarden, Haarlem or Utrecht. The rest of the cities like Kampen, Zwolle, Alkmaar, Amsterdam developed into a much more fragmented zones, although their canal parks are still reminding of the old fortifications. The same applies to the cities which were dismantled in the last of the four periods, because not all have been preserved. Nowadays, these areas are under renewed interest and manifested a multitude of spatial revitalisation strategies. These strategies vary from literal reconstructions, to revitalisation to conceptualisation. This last approach is using the heritage landscape to unify a diversity of bottomup projects along the 'fortification line' into a recreational zone for the entire city. In order to make well-informed decisions about the future of these fortification zones it is extremely important to understand the meaning of the existing elements both in the context of their history and in context of the new urbanism which strives to integrate a multitude of interests. This article provides a first glimpse at the history of the Dutch fortification zones and shows that these zones have always been a 'battlefield' of different forces, conditions and interests. It is important to develop ideas on how to accommodate all interest and spatial needs, such that the former fortification zones become urban spaces with their own urban identity.

\section{References}

[1] Cremers, E., Kaaij, F. \& Steenbergen, C.M., Bolwerken als stadsparken. Nederlandse Stadswandelingen in de 19 e en 2e eeuw, DUP: Delft, pp. 3-4, 66-69, 1981.

[2] Steenbergen, C., de Jong, E. \& van der Vlist, E., Eene aangename publieke wandeling, een schets van historische stads-en singelparken, Walburg pers: Zutphen, 1997.

[3] Sneep, J., Treu, H.A., Tydeman, M., Vesting, vier eeuwen vestingbouw in Nederland, Walburg Pers: Zutphen, pp.112-117, 1982.

[4] Kaashoek, A., Jansen, K. \& Belt, M., Visie Leidse singels; het langste park van Nederland sinds 1659, Leiden, pp. 6-12, 2011.

[5] Huizinga, S. \& Deinema, J., Vestingsteden, Atrium: Alphen aan den Rijn, pp. 3-6, pp. 6-16, 1994.

[6] Besemer J.W.C, Het beheer en gebruik van voormalige (stedelijke) vestingwerken, Monumenten, 3(5), pp. 17-19, 1982. 
[7] Akerboom, J., Kramer, W. \& van Oirschot, A., Vestingsteden in Nederland, Monumenten, 3(5), 1982.

[8] Will, C., Sterk Water, de Hollandse Waterlinie, Matrijs: Utrecht, p. 25, 2002

[9] Verschuure-Stuip, G.A., Project New Dutch waterline and project Arcadian landscapes; guidelines for new spatial development based on heritage, AESOP conference 2014, Delft/ Utrecht, 2014.

[10] J. Sneep, Treu, H.A., Tydeman, M. \& van den Heuvel, C., Vesting; vier eeuwen vestingbouw in Nederland, Walburg pers: Zutphen, pp. 111-125, 1982.

[11] Kips, D., Gids voor de vestingwerken van Naarden, http://www.vestingnaarden.nl/, visited 10-05-2014.

[12] Smook R.A.F., Binnensteden veranderen, atlas van het ruimtelijk veranderingsproces van Nederlandse binnensteden in de laatste anderhalve eeuw, Walburg pers: Zutphen, pp. 110-115, p. 138, 1984.

[13] Abma, R., Boersema, J., Buylinckx, J., Hoeks, H., Klein Lankhorst, J., de Heiden, H., Eliens, F. \& Verheijen, R., Stad aan de Waal. Nijmegen van Romeinse tot moderne stad, Dwarsstap: Nijmegen, p. 87, 1984.

[14] Janssen, J., Luiten, E., Renes, H., Rouwendal, J., Faber, O., Pen, C.J. \& Stegemeijer,E., Karakterschetsen, nationale onderzoeksagenda, dl 1 kennisagenda, Den Haag, pp.11-25, 2014.

[15] Overdiep, G., H.R.J. Conens, De vesting Bourtagne herbouwd, REGIOProjekt Groningen, Groningen, 1993.

[16] Nn., Landschapsarchitectuur en stedenbouw in Nederland, 2007/2008, Blauwdruk, Wageningen, pp.102-109, 2009.

[17] Veenstra J., Chaldova, E., Jongerius, R. \& van Weeren, B e.a., Beeldkwaliteitsplan singelpark, Gemeente Leiden, p. 19, pp. 6-12, 2014. 